\section{Effect of Sowing Date and Harvest Schedule on Organic Spinach Grown during the Winter in High Tunnels}

\author{
Robert F. Heyduck ${ }^{1,3,6}$, Steven J. Guldan ${ }^{1,4}$, and Ivette Guzmán ${ }^{2,5}$
}

ADDITIONAL INDEX WORDs. hoop house, polytunnel, row covers, season extension, leafy greens

SUMMARY. In a two-part study, we examined the effect of sowing date and harvest schedule on the yield of spinach (Spinacia olevacea) grown during the winter in $16 \times$ 32 -ft-high tunnels in northern New Mexico. Each part of the study was conducted for two growing seasons and took place between 2012 and 2015. In Study A (2012-13 and 2013-14), spinach was sown four times at roughly 2-week intervals (mid-October, early November, mid-November, and early December) and plant density (plants per square foot), plant height (centimeters), and yield (grams per square foot) were measured for three harvests in mid-January, mid-February, and mid-March. The earliest sowing date had the least-dense stands, and plant density increased with each subsequent sowing. The two earliest sowing dates had significantly higher season-long yield than the later two sowings. In Study B (2013-14 and 2014-15), all plots were sown in mid-October, but harvest schedule treatments were staggered such that harvests began at $9,11,13$, or 15 weeks after sowing and continued at irregular intervals. Treatment 2 , with harvests beginning after 11 weeks, had the greatest season-long yield, slightly greater than when harvests began at 9 weeks, and significantly more than when harvest began 13 weeks or later. More importantly, a staggered harvest schedule can provide spinach weekly for direct marketing opportunities.

$\mathrm{T}$ The demand for locally and organically grown produce has grown over the past 15 years (Halweil, 2002; Hinrichs, 2003; Morrison et al., 2011; Peters et al., 2009; Rose et al., 2008). This demand stems primarily from the general

Received for publication 21 Dec. 2018. Accepted for publication 12 Mar. 2019.

Published online 22 April 2019.

We thank Drs. Shengrui Yao and Owen Burney from New Mexico State University for reviewing this manuscript. We also thank David Salazar, David Archuleta, Esteban Herrera, Margarito Hernandez, and Melanie Kirby for their technical assistance. Salaries and research support were provided by state and federal Hatch funds appropriated to the New Mexico Agricultural Experiment Station. In addition, we gratefully acknowledge the Western Region Sustainable Agriculture Research and Education Program for partial funding for this research through Project SW09-041.

${ }^{1}$ Sustainable Agriculture Science Center at Alcalde, New Mexico State University, Alcalde, NM 87511

${ }^{2}$ Department of Plant and Environmental Sciences, New Mexico State University, Las Cruces, NM 88003

${ }^{3}$ Senior Ag Research Assistant

${ }^{4}$ Superintendent and Professor

${ }^{5}$ Assistant Professor

${ }^{6}$ Corresponding author. E-mail: rheyduck@nmsu.edu.

This is an open access article distributed under the CC BY-NC-ND license (https://creativecommons.org/ licenses/by-nc-nd/4.0/).

https://doi.org/10.21273/HORTTECH04257-18 public, but the United States has also developed several federal programs, such as the U.S. Department of Agriculture (USDA) Healthy Hunger-Free Kids Act, with a mission to bring more nutritious food to school kitchens (USDA, 2017a), and the USDA Farm to School Grant Program, dedicated to implementing projects focused on increasing local foods accessibility in public schools (USDA, 2017b). This presents a challenge for farmers who need to supply produce throughout the year, including the late fall, winter, and early spring months, when production is usually lowest. Winter farmers' markets also provide farmers with increased opportunities. The number of winter farmers' markets in the United States increased 38\% from 2010 to 2011 alone (Neal, 2011). The New Mexico Department of Agriculture (NMDA) reported 75 statewide farmers' markets with combined sales of up to $\$ 9$ million per year and according to the New Mexico Farmer's Marketing Association (NMFMA), 11 of these are open during the winter (NMDA, 2015; NMFMA, 2019).

To help farmers gain access to winter markets and help provide nutritious foods year-round to schools, the 2008 U.S. Farm Bill also launched the Seasonal High Tunnel Initiative program through the Natural Resource Conservation Service Environmental Quality Incentives Program. High tunnels (i.e., hoop houses) are defined as a plastic-covered, passively heated, walk-in, semipermanent structure sited on field soil (Jimenez et al., 2005). Although high tunnels were initially developed in the United States (Emmert, 1955), their adoption has been slower there than in other countries (Blomgren and Frisch, 2007). High tunnels can reduce damage to crops (Upson, 1998) and ameliorate wide diurnal temperature swings and other unpredictable growing conditions (Lamont and Orzolek, 2003). High tunnels change the growing environment equivalent to moving three USDA Plant Hardiness Zones to the south (Coleman, 2009; Wells and Loy, 1993). As of 2009, China was the leader in high tunnel vegetable production with 889,596 acres and the United States trailed behind with 12,355 acres (Lamont, 2009). High tunnels in the United States have been used to grow a variety of crops ranging from tomato (Solanum lycopersicum) to cut flowers (Knewtson et al., 2010); however, management practices vary

\begin{tabular}{llll}
\hline $\begin{array}{l}\text { Units } \\
\begin{array}{l}\text { To convert U.S. to SI, } \\
\text { multiply by }\end{array}\end{array}$ & U.S. unit & SI unit & $\begin{array}{l}\text { To convert SI to U.S., } \\
\text { multiply by }\end{array}$ \\
\hline 29.5735 & $\mathrm{fl} \mathrm{oz}$ & $\mathrm{mL}$ & 0.0338 \\
0.3048 & $\mathrm{ft}$ & $\mathrm{m}$ & 3.2808 \\
0.0929 & $\mathrm{ft}^{2}$ & $\mathrm{~m}^{2}$ & 10.7639 \\
0.0283 & $\mathrm{ft}^{3}$ & $\mathrm{~m}^{3}$ & 35.3147 \\
2.54 & inch $(\mathrm{es})$ & $\mathrm{cm}$ & 0.3937 \\
0.4536 & $\mathrm{lb}$ & $\mathrm{kg}$ & 2.2046 \\
1.1209 & $\mathrm{lb} / \mathrm{acre}$ & $\mathrm{kg} \cdot \mathrm{ha}^{-1}$ & 0.8922 \\
4.8824 & $\mathrm{lb} / \mathrm{ft}^{2}$ & $\mathrm{~kg} \cdot \mathrm{m}^{-2}$ & 0.2048 \\
28.3495 & $\mathrm{Oz}$ & $\mathrm{g}$ & 0.0353 \\
0.3052 & $\mathrm{Oz} / \mathrm{ft}^{2}$ & $\mathrm{~kg} \cdot \mathrm{m}^{-2}$ & 3.2771 \\
$\left({ }^{\circ} \mathrm{F}-32\right) \div 1.8$ & ${ }^{\circ} \mathrm{F}$ & ${ }^{\circ} \mathrm{C}$ & $\left({ }^{\circ} \mathrm{C} \times 1.8\right)+32$
\end{tabular}


from one farmer to the next, even when producing the same crop (Knewtson et al., 2010). Moreover, new agricultural trends demand new technologies and validated practices, thus research is needed to assist small farmers in producing high-quality food for their local communities, especially during the winter.

Spinach is a valuable fresh-market item with high levels of vitamins, folic acid, potassium, and antioxidants, and has relatively high resistance to freezing temperatures (Maynard and Hochmuth, 2007). According to the Organic Farming Research Foundation's Fourth National Organic Farmers' Survey, spinach accounted for the largest acreage among organic vegetable crops grown (Walz, 2004). Spinach also has the potential to maximize winter production because leafy material can be harvested several times ("cut and come again") with a relatively short regrowth period (35-50 d or 5-7 weeks) (Swiader and Ware, 2002). In Oklahoma, Donnell et al. (2011) sowed spinach in high tunnels in September and were able to harvest four times: November, December, January, and February. In our high tunnel study, we examined the effect of fall sowing date (Study A) and staggered harvests of October-sown (Study B) spinach on winter-season yields.

\section{Materials and methods}

STUDY LOCATION. The study was conducted on USDA-certified organic acreage at the New Mexico State University Sustainable Agriculture Science Center at Alcalde, NM, at an elevation of $5680 \mathrm{ft}$ and average annual precipitation of 10.0 inches [Western Regional Climate Center (WRCC), 2019]. Based on 2011-17 data from the WRCC weather station, the average last spring freeze $\left(32{ }^{\circ} \mathrm{F}\right)$ date was 9 May and the average first fall freeze date was 9 Oct., for a 153-d frost-free growing season (New Mexico Climate Center, 2019). In Alcalde, the average maximum daily temperature in January, the coldest month, is $\left(45.7^{\circ} \mathrm{F}\right)$ and the average minimum daily temperature in January is $15.2^{\circ} \mathrm{F}$ (WRCC, 2019). The study was conducted on Fruitland sandy loam soil [coarse-loamy, mixed, calcareous, mesic Typic Torriorthents (USDA, 2008)].
A series of six high tunnels of identical design were constructed in 2009 , and two of them were used for these studies: both seasons of Study A occurred in high tunnel (HT) \#l, whereas season 1 of Study B was in HT\#3 and season 2 was in HT\#l. High tunnels were $16 \times 32 \mathrm{ft}$ with the longest dimension in east-west alignment. This orientation provides a large south-facing sidewall that improves the transmission of solar radiation when the sun is at lower angles in the northern hemisphere winter (Giacomelli, 2009). The design is based on Jimenez (2005), but was modified to have sidewalls and endwalls framed by dimensional lumber (Hecher et al., 2014). The high tunnel was constructed with 3 -ft-high sidewalls, a peak height of $8.5 \mathrm{ft}$, and $3 \times 7$-ft doors on both the west and east ends. The high tunnels had two layers of plastic inflated with a blower fan $\left[148 \mathrm{ft}^{3} / \mathrm{min}\right.$ (Inflation System Replacement Blower; FarmTek, Dyersville, IA)]. The first layer was a lightweight woven plastic and the second layer a heavyweight woven plastic (SOLARIG ROOF 140 and 172, respectively; J\&M Industries, Ponchatoula, LA), both containing an ultraviolet light inhibitor treatment.

SoIl Fertility MANAgement. Before trial establishment each season, $\approx 300 \mathrm{lb}$ of aged bovine manure was applied in the spring in the 512 $\mathrm{ft}^{2}$ high tunnel $[\approx 210,23$, and 222 $\mathrm{lb} /$ acre nitrogen $(\mathrm{N})$, phosphorus $(\mathrm{P})$, and potassium $(\mathrm{K})$, respectively] and incorporated with a small rototiller to a depth of $\approx 6$ inches. Manure nutrient content was assessed at the Colorado State University Soil, Water, and Plant Testing Laboratory (Ft. Collins) using ammonium bicarbonate-diethylenetriaminepentaacetic acid as the extract (Soltanpour and Schwab, 1977). Nitrate-N was determined by cadmium reduction using flow injection analysis (Dorich and Nelson, 1984), P using the molybdateblue colorimetric method (Bowman, 1988), and K by inductively coupled plasma (Munter et al., 1981). Subsequently, a cover crop of sudangrass (Sorghum $\times$ drummondii) was broadcast across the entire floor of the high tunnel. The cover crop was mown several times through the summer and mowed and incorporated with a small rototiller in late summer.

ExPERIMENTAL DESIGN. The high tunnel was divided into 24 plots (experimental units), 12 on each side of a central aisle, each $5 \mathrm{ft}$ long by $2 \mathrm{ft}$ wide and separated by a 7 -inch buffer, as shown in Fig. 1. Both Studies A and $\mathrm{B}$ were randomized complete block designs with four treatments and six blocks.

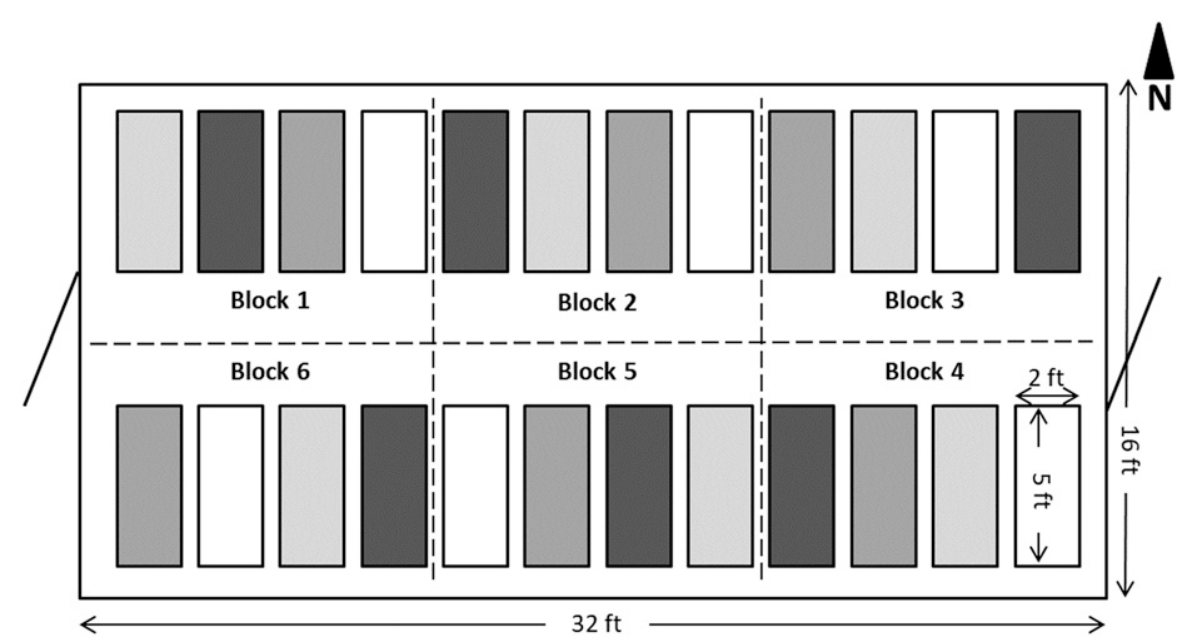

Fig. 1. Layout of experimental units in the high tunnels. Different shades represent a possible randomization of the four treatments. In Study A, there were four sowing dates for 'Bloomsdale Longstanding' spinach: 15 Oct., 1 Nov., 15 Nov., and 1 Dec. and in Study B, these were four harvest schedules (weeks from sowing to first harvest/weeks between first and second harvest/weeks between second and third harvest): 9/8/3 weeks, 11/7/3 weeks, 13/6/2 weeks, and $15 / 4 / 2$ weeks. Each round of the study was independently randomized. Alcalde, NM. $1 \mathrm{ft}=0.3048 \mathrm{~m}$. 
Crop establishment and MANAGEMENT. For each $2 \times 5$-ft plot, $5.6 \mathrm{~g}$ pure live seed of 'Bloomsdale Long Standing' spinach seed was and then broadcast across the plot, raked lightly, and then firmed by foot. Plots were irrigated as needed with sprinklers installed at the top of the high tunnels. On warm days, generally above $50{ }^{\circ} \mathrm{F}$ daytime ambient temperature, high tunnel doors were opened for venting. Plots were covered with $100 \%$ polypropylene, spun-bound fabric rowcovers (Agribon AG-15; J\&M Industries, Ponchatoula, LA), which rested directly on top of plants. Row cover was placed over the crop on 25 Nov. of each season in each study, but was removed for the final sowing in Study A, and for harvesting and occasional overhead irrigation application. Aphids (Aphis sp.) son of the second season of Study A, and Organic Materials Review Institute-listed pyrethrins (PyGanic EC 5.0; Valent U.S.A., Walnut Creek, CA) was applied twice between harvests.

STUdy A: SowINg DATE. Sowing dates were $\approx 15 \mathrm{~d}$ apart. In 2012 , spinach seed was sown on 15 Oct., 1 Nov., 15 Nov., and 30 Nov., and in 2013 was sown on 15 Oct., 31 Oct., 15 Nov., and 1 Dec. In each iteration mixed into a $12-\mathrm{fl} \mathrm{oz}$ cup of soil were noted on the spinach midsea-

of the study, spinach leaves were harvested a total of three times, and harvest dates were kept within 1 calendar day from season to season. Harvest dates for 2012 were 15 Jan., 12 Feb., and 12 Mar. In 2013, harvest dates were 15 Jan., 11 Feb., and 11 Mar. However, in both seasons, treatment 4 (sown 30 Nov./1 Dec.) did not have enough leaf matter to justify harvesting on the first harvest date (45 d after sowing). As a result, the first harvest for treatment 4 was conducted when other treatments were harvested the second time. Second and third harvests were made at 28-d intervals for the duration of each season (until plants bolted).

Study B: Harvest schedule. All plots in Study B were sown on 15 Oct. and four harvest schedules were imposed as treatments. Spinach greens from each of the four treatments were initially harvested by clipping at $9,11,13$, and 15 weeks after sowing, respectively, followed by a second harvest at $8,7,6$, and 4 weeks after the first harvest. However, all treatments had a 20- to 21-week growing season, and all harvest schedules ended in a relatively brief 2 - to 3 -week regrowth period before the final harvest. Figure 2 illustrates the timeline of sowing and harvesting for both studies.

HaRvesting METHOD AND YIELD DATA COLLECTION. Harvesting method

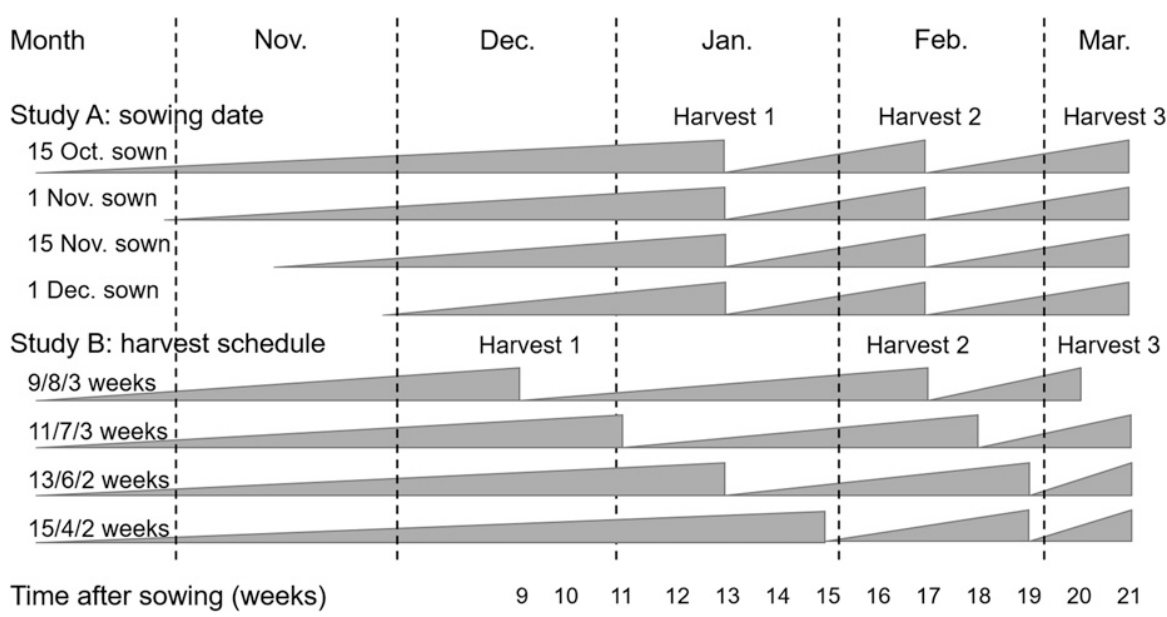

Fig. 2. Sowing and harvesting schedules for 'Bloomsdale Longstanding' spinach. In Study A, spinach was sown on four dates (15 Oct., 1 Nov., 15 Nov., and 1 Dec.) and harvested on three dates [15 Jan., 12 Feb., and 12 Mar. 2013 (season 1) and 15 Jan., 11 Feb., and 11 Mar. 2014 (season 2)]. In Study B, all spinach was sown on 15 Oct., but harvested according to schedule. Labels in the diagram refer to weeks from sowing to first harvest/weeks until second harvest/weeks until final harvest. Wedges represent growth periods and truncations on the right-hand side of each wedge denote harvests. was consistent across Studies A and B. Before harvest, plant height was measured at three points down the centerline of each plot and these were averaged. The whole tops of plants from each entire plot were cut with scissors to a height of $\approx 1$ inch above the ground and allowed to regrow until the following harvest. Unmarketable leaves were usually sorted out as they were harvested and were not included in fresh weight yield. However, on the 21 Jan. 2015 harvest in Study B, these leaves were so numerous that they were sorted and weighed separately to estimate harvest loss. Following each harvest, plant counts for each plot were taken by dividing each plot into three sections and plant density (plants per square foot) was calculated. Immediately following each harvest, fresh weights for each plot were acquired with a portable digital scale and recorded in grams.

Temperature MONITORING. Temperatures were recorded at 30-min intervals throughout the season using temperature data loggers (HOBO U12; Onset Computer Corp., Bourne, MA). Temperature sensors were placed $1 \mathrm{ft}$ above the soil in solar radiation shields and horizontally 3 inches below the soil surface at each of three locations: 1) outside the high tunnel; 2) inside the high tunnel, uncovered; and 3) inside the high tunnel under the rowcover material.

Statistical analysis. All data for both studies were analyzed using the General Linear Models procedure in Minitab (version 18; Minitab, State College, PA). One plot in season 1 , Study A had low plant counts and delayed growth, and yield data were collected only for the final harvest. Because this plot was not harvested according to treatment protocol, it was considered missing data in the analysis of yield, but was included for analysis of plant stands. All effects were considered fixed. The statistical model was: $Y_{i j}=\mu+\alpha_{i}+\tau_{j}+\alpha \tau_{i j}+\varepsilon_{i j k}$, where $\alpha$ represents the treatment effect, $\tau$ the season effect, and $\varepsilon$ the error. We also tested for interaction between treatment and season. We mainly examined season total yield, but also analyzed each harvest individually to better understand the effect of planting date on production at different times in the year. When 
Table 1. Study A analysis of variance table showing sources of variation in plant height, plant density, and fresh weight yield of 'Bloomsdale Longstanding' spinach sown in $16 \times 32-\mathrm{ft}(4.9 \times 9.8-\mathrm{m})$-high tunnels for three harvests and season total harvest at Alcalde, NM. Spinach seed was broadcast in $2 \times 5$-ft $(0.6 \times 1.5 \mathrm{~m})$ plots 15 Oct., 1 Nov., 15 Nov., and 1 Dec. and harvested on 15 Jan., 12 Feb., and 12 Mar. 2013 (season 1) and 15 Jan., 11 Feb., and 11 Mar. 2014 (season 2 ).

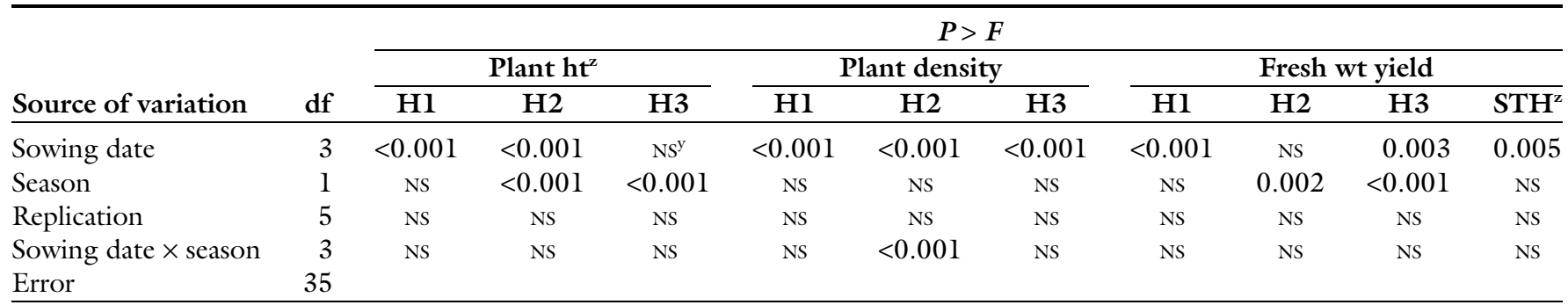

${ }^{\mathrm{z}} \mathrm{Hl}=$ harvest $1, \mathrm{H} 2$ = harvest $2, \mathrm{H} 3$ = harvest $3, \mathrm{STH}=$ season total harvest.

${ }^{y}$ Nonsignificant at $P \leq 0.05$.

Table 2. Study A means for plant height, plant density, and fresh weight yield of 'Bloomsdale Longstanding' spinach sown in $16 \times 32-\mathrm{ft}(4.9 \times 9.8-\mathrm{m})$-high tunnels for three harvests and season total harvest at Alcalde, NM. Spinach seed was broadcast in $2 \times 5 \mathrm{ft}(0.6 \times 1.5 \mathrm{~m}) 15$ Oct., 1 Nov., 15 Nov., and 1 Dec. and harvested on 15 Jan., 12 Feb., and 12 Mar. 2013 and 15 Jan., 11 Feb., and 11 Mar. 2014.

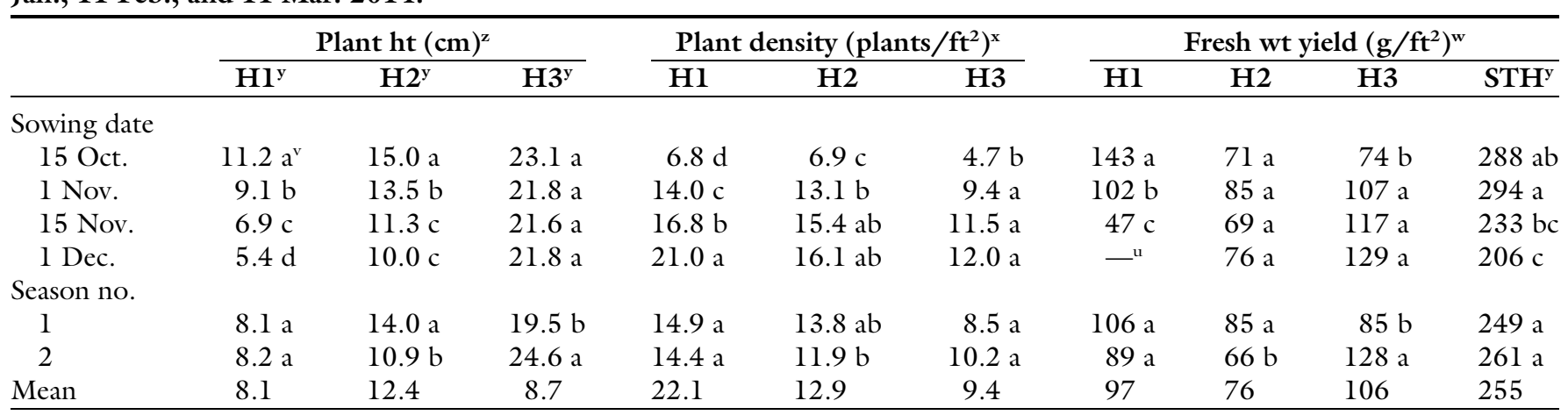

${ }^{\mathrm{z}}$ Average of three measurements made across the plot; $1 \mathrm{~cm}=0.3937$ inch.

${ }^{y} \mathrm{H} 1=$ harvest $1, \mathrm{H} 2=$ harvest $2, \mathrm{H} 3=$ harvest $3, \mathrm{STH}=$ season total harvest.

${ }^{\mathrm{x}}$ Based on total plant count for entire $10-\mathrm{ft}^{2}\left(0.9 \mathrm{~m}^{2}\right)$ plot; 1 plant $/ \mathrm{ft}^{2}=10.7639$ plants $/ \mathrm{m}^{2}$.

${ }^{\mathrm{w}}$ Fresh weight yield based on total fresh weight harvested from $10-\mathrm{ft}^{2} \mathrm{plot} ; \mathrm{l} \mathrm{g} / \mathrm{ft}^{2}=0.0353 \mathrm{oz} / \mathrm{ft}^{2}=0.0108 \mathrm{~kg} \cdot \mathrm{m}^{-2}$.

${ }^{\mathrm{v}}$ Mean with same letters within columns and section (sow date/season) are not significantly different by Fisher's least significant difference test at $P \leq 0.05$.

"The 1 Dec. sowing was not harvested on harvest 1, 11 Jan.

significant effects were detected within main effects, Fisher's least significant difference test was performed to detect significant differences between means at $P<0.05$. Residuals of all response variables were checked for normality and constant variance to ensure they met analysis of variance assumptions. Yields are reported as grams per square foot.

\section{Results and discussion}

Study A: Sowing Date. Plant height at harvest varied significantly by season at the second and third harvest, and across treatments at the first two harvests (Table 1). Overall mean plant height at time of harvests was $14.2 \mathrm{~cm}$, but mean height per plot varied from 3.3 to $31.0 \mathrm{~cm}$ depending on treatment and harvest. Difference in plant height was most pronounced at harvest 1 , when plants sown on 15 Oct. were $11.2 \mathrm{~cm}$ tall, but those sown 1 Dec. were only 5.4 $\mathrm{cm}$ tall (Table 2). By the second harvest, the first and second sowings were taller than the third and fourth, but by the third harvest, there were no differences in plant height.

Plant density averaged across all seasons, treatments, and harvests was 12.6 plants $/ \mathrm{ft}^{2}$, but ranged widely from 0.7 to 27.1 plants $/ \mathrm{ft}^{2}$. Plant density between the two seasons was not significantly different but did differ significantly by sowing date (Table 1). The earliest sowing date had the least-dense stands (6.8 plants $/ \mathrm{ft}^{2}$ ) with stands increasing in density with each of the three remaining sowing dates $(14.0,16.8$, and 21.0 plants $/ \mathrm{ft}^{2}$, respectively) (Table $2)$. The lower number of plants for the first sowing date was perhaps due to high temperatures impeding germination at this time. Spinach germination declines progressively above $68^{\circ} \mathrm{F}$ (Katzman et al., 2001) and temperatures above $77^{\circ} \mathrm{F}$ are known to favor the release of inhibiting agents from the pericarp (Suganuma and Ohno, 1984). Across all treatments, plant counts also decreased at each subsequent harvest (from 14.7 to 12.9 to 9.4 plants/ $\mathrm{ft}^{2}$ ), probably due to cutting below the growth point or competition from neighboring plants (Table 2). Plant density and yield did not correlate strongly in Study A.

Total season-long fresh weight yields did not differ significantly between seasons in this study, but they did vary significantly by treatment (Table 1). The two earliest sowing dates had higher total yield on average $\left(288\right.$ and $294 \mathrm{~g} / \mathrm{ft}^{2}$, respectively) than the two later sowing dates $\left(232\right.$ and $205 \mathrm{~g} / \mathrm{ft}^{2}$, respectively) (Table 2, Fig. 3). However, there was an interesting season $x$ treatment interaction, with the earliest sowing date yielding the highest 
in the second season, but the second sowing date yielding the highest in the first season. In season 1 of the study, plots with sparse stands and low yield brought down the yield of the earliest sowing at all harvests. Suboptimal weather conditions at the time of sowing can drastically reduce stand density and yield, so balancing the earliness of a crop with total season-long yield potential can be difficult. Regardless, the earliest two sowing dates reliably yielded more than the latter two.

When examining individual harvests across sowing date treatments, a clear pattern emerged. Yield at the first harvest (15 Jan.) varied significantly among the first three sowing dates ( 1 Dec. sowing date not

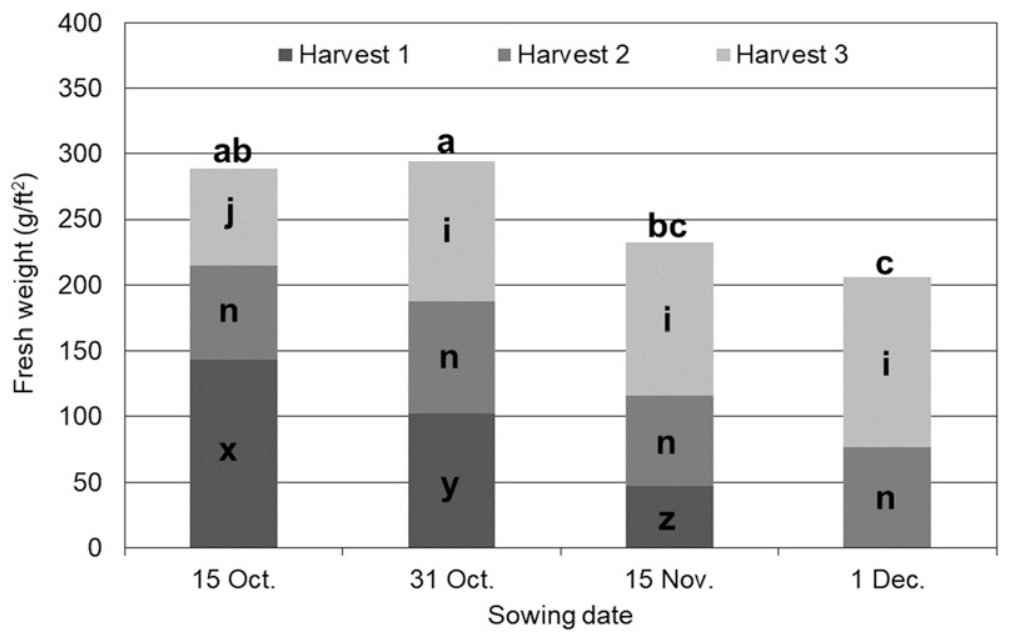

Fig. 3. Individual harvest yields and season total harvest for Study A. 'Bloomsdale Longstanding' spinach sown on 15 Oct., 1 Nov., 15 Nov., and 1 Dec. and harvested on 15 Jan., 12 Feb., and 12 Mar. 2013 (season 1) and 15 Jan., 11 Feb., and 11 Mar. 2014 (season 2) at Alcalde, NM. Means with the same letter within harvests are not significantly different by Fisher's least significant difference $\alpha=0.05 ; 1 \mathrm{~g} / \mathrm{ft}^{2}=0.0353 \mathrm{oz} / \mathrm{ft}^{2}=0.0108 \mathrm{~kg} \cdot \mathrm{m}^{-2}$. harvested) (Table 1). The more time plants had to grow before the first harvest, the greater the yield. Mean yield $( \pm S D)$ from the first harvest was $95 \pm 54 \mathrm{~g} / \mathrm{ft}^{2}$. By the second and third harvests, yields were less variable. Mean yield for second harvest was $\left(77 \pm 23 \mathrm{~g} / \mathrm{ft}^{2}\right)$ and third harvest was $\left(104 \pm 41 \mathrm{~g} / \mathrm{ft}^{2}\right)$ (Table 2$)$. This seems to show that earlier sowings gained no yield advantage at later harvests, but had an advantage earlier in the season.

Study B: Harvest schedule Treatments. In Study A, the midOctober sowing date had the highest combined season-long total yield averaged over both seasons of the study, although it is possible that even earlier sowing dates could be more productive given the proper growing conditions. This sowing date was chosen for Study B in an attempt to determine the maximum potential season-long yield of spinach planted early in the season, but harvested at different intervals. First harvests were 9 to 15 weeks after sowing, and subsequent harvests followed from 2 to 8 weeks after a previous cut. We mainly examined season-long yield, but also took into practical consideration the seasonal distribution of yield as it pertains to the small-scale grower requiring weekly product.

There was significant variation in plant height across seasons and treatments in the study (Table 3); however, overall mean plant height at time of harvest across all treatments and harvests was $14.2 \mathrm{~cm}$. Plant heights across treatments and harvests ranged from 7.9 to 23.6 $\mathrm{cm}$. There did not, however, appear to be any trend to plant height across harvests and treatments. Mean plant heights for the three harvests are shown in Table 4.

Plant densities across all harvests, treatments, and seasons averaged 14.2 plants $/ \mathrm{ft}^{2}$, but ranged widely from 2.7 to 30.8 plants $/ \mathrm{ft}^{2}$. Plant densities varied significantly across treatments and seasons (Table 3 ). For all treatments, plant counts decreased for each successive harvest, as seen in Study A, again, probably due to cutting below the growth point, freeze damage, or competition from neighboring plants. Plant densities (Table 4) were also higher on average in season 2 (at first harvest) $\left(21.6\right.$ plants $\left./ \mathrm{ft}^{2}\right)$ than season $\mathrm{l}\left(\mathrm{l} 3.7\right.$ plants $\left./ \mathrm{ft}^{2}\right)$.

Table 3. Study B analysis of variance table showing sources of variation in plant height, plant density, and fresh weight yield of 'Bloomsdale Longstanding' spinach sown in $16 \times 32-\mathrm{ft}(4.9 \times 9.8-\mathrm{m})$-high tunnels for three harvests and season total harvest at Alcalde, NM. For two seasons, spinach seed was broadcast in $2 \times 5$ - $\mathrm{ft}(0.6 \times 1.5-\mathrm{m})$ plots 15 Oct. and harvested from 9 Dec. through 4 Mar. according to four harvest schedules: 9, 17, and 20 weeks after sowing; 11, 18, and 21 weeks after sowing; 13, 19, and 21 weeks after sowing; and 15, 18, and 21 weeks after sowing.

\begin{tabular}{|c|c|c|c|c|c|c|c|c|c|c|c|}
\hline \multirow[b]{3}{*}{ Source of variation } & \multirow[b]{3}{*}{ df } & \multicolumn{10}{|c|}{$P>F$} \\
\hline & & \multicolumn{3}{|c|}{ Plant ht ${ }^{\mathrm{z}}$} & \multicolumn{3}{|c|}{ Plant density } & \multicolumn{4}{|c|}{ Fresh wt yield } \\
\hline & & HI & $\mathrm{H} 2$ & H3 & $\mathrm{HI}$ & $\mathrm{H} 2$ & H3 & H1 & $\mathrm{H} 2$ & H3 & $\mathrm{STH}^{\mathrm{z}}$ \\
\hline Season & 1 & 0.004 & 0.001 & NS & $<0.001$ & $<0.001$ & $<0.001$ & NS & $<0.001$ & NS & $<0.001$ \\
\hline Replication & 5 & NS & NS & NS & NS & NS & NS & 0.001 & NS & NS & 0.006 \\
\hline Harvest schedule $\times$ season & 3 & NS & NS & 0.005 & NS & NS & $-^{x}$ & $<0.001$ & NS & $<0.001$ & NS \\
\hline
\end{tabular}

${ }^{\mathrm{z}} \mathrm{Hl}=$ harvest $1, \mathrm{H} 2$ = harvest $2, \mathrm{H} 3$ = harvest $3, \mathrm{STH}=$ season total harvest.

y Nonsignificant at $P \leq 0.05$.

${ }^{\mathrm{x}}$ Plant density not measured on harvest 3 of second season for treatments 2,3 , and 4 (week 21 ). 
Table 4. Study B means for plant height, plant density, and fresh weight yield of 'Bloomsdale Longstanding' spinach at three harvests, as well as season total harvest at Alcalde, NM. For two seasons, spinach seed was broadcast in $2 \times 5$ - $\mathrm{ft}(0.6 \times 1.5-\mathrm{m})$ plots 15 Oct. and harvested from 9 Dec. through 4 Mar. according to four harvest schedules: 9 , 17, and 20 weeks after sowing; 11,18 , and 21 weeks after sowing; 13, 19, and 21 weeks after sowing; and 15, 18, and 21 weeks after sowing.

\begin{tabular}{|c|c|c|c|c|c|c|c|c|c|c|}
\hline \multirow[b]{2}{*}{ Harvest } & \multicolumn{3}{|c|}{ Plant ht $(\mathrm{cm})^{\mathrm{z}}$} & \multicolumn{3}{|c|}{ Plant density (plants $\left./ \mathrm{ft}^{2}\right)^{\mathrm{x}}$} & \multicolumn{4}{|c|}{ Fresh wt yield $\left(\mathrm{g} / \mathrm{ft}^{2}\right)^{\mathrm{w}}$} \\
\hline & $\mathbf{H}^{\mathbf{y}}$ & $\mathrm{H} 2^{\mathrm{y}}$ & $\mathbf{H}^{\mathbf{y}}$ & $\mathrm{Hl}$ & $\mathrm{H} 2$ & H3 & $\mathrm{Hl}$ & $\mathrm{H} 2$ & H3 & $\mathrm{STH}^{\mathrm{y}}$ \\
\hline \multicolumn{11}{|c|}{ Harvest schedule $(\mathrm{wk})^{\mathrm{v}}$} \\
\hline $11 / 7 / 3$ & $12.3 \mathrm{bc}$ & $14.8 \mathrm{~b}$ & $16.0 \mathrm{a}$ & $19.3 \mathrm{ab}$ & $14.8 \mathrm{a}$ & $8.7 \mathrm{ab}$ & $162 \mathrm{a}$ & $129 \mathrm{a}$ & $71 \mathrm{a}$ & $362 \mathrm{a}$ \\
\hline $13 / 6 / 2$ & $13.3 \mathrm{ab}$ & $18.0 \mathrm{a}$ & $13.8 \mathrm{a}$ & $16.0 \mathrm{bc}$ & $14.5 \mathrm{a}$ & $6.6 \mathrm{~b}$ & $128 \mathrm{~b}$ & $130 \mathrm{a}$ & $48 \mathrm{~b}$ & $290 \mathrm{bc}$ \\
\hline $15 / 4 / 2$ & $14.0 \mathrm{a}$ & $15.3 \mathrm{~b}$ & $11.3 \mathrm{~b}$ & $14.4 \mathrm{c}$ & $15.0 \mathrm{a}$ & $5.7 \mathrm{~b}$ & $130 \mathrm{~b}$ & $85 \mathrm{~b}$ & $38 \mathrm{~b}$ & $253 c$ \\
\hline 2 & $13.6 \mathrm{a}$ & $14.2 \mathrm{~b}$ & $13.8 \mathrm{a}$ & $21.6 \mathrm{a}$ & $18.8 \mathrm{a}$ & $19.1 \mathrm{a}$ & $132 \mathrm{a}$ & $90 \mathrm{~b}$ & $57 \mathrm{a}$ & $272 \mathrm{~b}$ \\
\hline Mean & 12.8 & 15.5 & 13.8 & 17.7 & 14.9 & 10.1 & 139 & 114 & 57 & 306 \\
\hline
\end{tabular}

${ }^{\mathrm{z}}$ Average of three measurements made across the plot; $1 \mathrm{~cm}=0.3937$ inch.

${ }^{\mathrm{y}} \mathrm{Hl}=$ harvest $1, \mathrm{H} 2=$ harvest $2, \mathrm{H} 3=$ harvest $3, \mathrm{STH}=$ season total harvest.

${ }^{\mathrm{x}}$ Based on total plant count for entire $10-\mathrm{ft}^{2}$ plot $\left(0.9 \mathrm{~m}^{2}\right) ; 1$ plant $/ \mathrm{ft}^{2}=10.7639$ plants $/ \mathrm{m}^{2}$

${ }^{\mathrm{w}}$ Fresh weight yield based on total fresh weight harvested from $10-\mathrm{ft}^{2} \mathrm{plot} ; \mathrm{l} \mathrm{g} / \mathrm{ft}^{2}=0.0353 \mathrm{oz} / \mathrm{ft}^{2}=0.0108 \mathrm{~kg} \cdot \mathrm{m}^{-2}$

"Treatments are described as weeks from sowing to first harvest/weeks between first and second harvest/weeks between second and third harvest.

${ }^{\text {u} M e a n ~ w i t h ~ s a m e ~ l e t t e r s ~ w i t h i n ~ c o l u m n s ~ a n d ~ s e c t i o n ~(t r e a t m e n t / s e a s o n) ~ a r e ~ n o t ~ s i g n i f i c a n t l y ~ d i f f e r e n t ~ b y ~ F i s h e r ' s ~ l e a s t ~ s i g n i f i c a n t ~ d i f f e r e n c e ~ t e s t ~ a t ~} P \leq 0.05$.

Total season-long fresh weight yields differed significantly between seasons and treatments in this study, and there was significant interaction between these factors at the first and third harvest. Season 1 saw a higher mean yield $\left(339 \mathrm{~g} / \mathrm{ft}^{2}\right)$ than season 2 $\left(272 \mathrm{~g} / \mathrm{ft}^{2}\right)$, but the ranking of treatment yields across seasons was similar (Fig. 4, Table 4). Treatment 2 had the greatest mean season-long total (361 $\left.\mathrm{g} / \mathrm{ft}^{2}\right)$ followed by treatment $1(318$ $\left.\mathrm{g} / \mathrm{ft}^{2}\right)$, treatment $3\left(290 \mathrm{~g} / \mathrm{ft}^{2}\right)$, and treatment $4\left(252 \mathrm{~g} / \mathrm{ft}^{2}\right)$.

Yields across all treatments declined with each subsequent harvest, as shown in Fig. 4. Mean yield for harvest 1 was $139 \mathrm{~g} / \mathrm{ft}^{2}$, followed by 114 and $57 \mathrm{~g} / \mathrm{ft}^{2}$ for harvests 2 and 3 , respectively (Table 4). For all four treatments, the first harvest had the longest time to grow $(9,11,13$, and 15 weeks, respectively) and was followed by a second harvest at 17,18 , or 19 weeks, respectively, after the 15 Oct. sowing. The second harvest allowed for $8,7,6$, and 4 weeks of regrowth after the first harvest for the four treatments, respectively. The final harvest was 20 weeks after sowing for treatment 1 and 21 weeks after sowing for all other treatments ( 2 weeks after previous cut for treatments 1 and 2 , and 3 weeks after previous cut for treatments 3 and 4). This complex staggering of harvest times makes it difficult to compare yield at different times throughout the season and for different lengths of time allowed for regrowth.

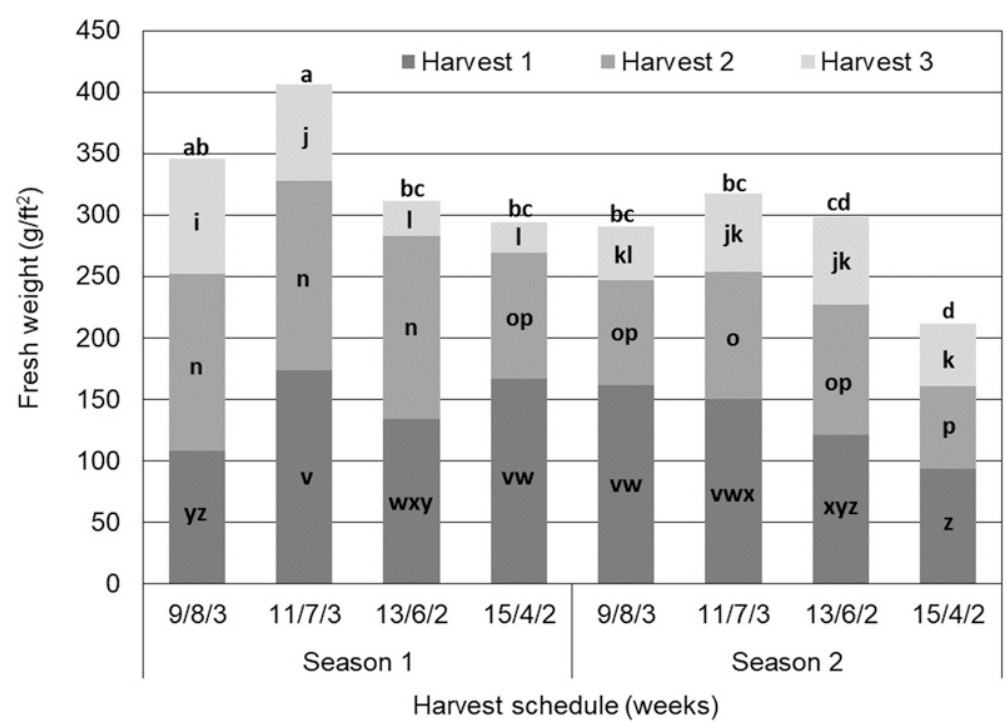

Fig. 4. Season total yield for Study B. 'Bloomsdale Longstanding' spinach sown on 15 Oct. and harvested at four different harvest schedules at Alcalde, NM. Categories on the $\mathrm{x}$-axis are the harvest schedule treatments defined by weeks from sowing to first harvest/weeks to second harvest/weeks to final harvest. Means with the same letter within harvests are not significantly different by Fisher's least significant difference $\alpha=0.05 ; 1 \mathrm{~g} / \mathrm{ft}^{2}=0.0353 \mathrm{oz} / \mathrm{ft}^{2}=0.0108 \mathrm{~kg} \cdot \mathrm{m}^{-2}$.

Based on this two-part study, several generalizations can be made. First, earlier sowing dates result in greater and earlier yields. Second, despite increasing temperatures and daylength, final harvests (mid-March) in Study B averaged only $57 \mathrm{~g} / \mathrm{ft}^{2}$. A possible explanation could be that these plants had only 2 to 3 weeks to regrow from previous harvests. In Study A, the final harvests at roughly the same time yielded an average of $106 \mathrm{~g} / \mathrm{ft}^{2}$, but had 4 weeks to regrow after the previous cut. In both seasons of Study B, harvests 13 weeks from sowing had severely declining quality (yellow and slimy lower leaves, frost damage, and necrotic leaf edges). On the 21 Jan. 2015 harvest, these senescing leaves accounted for $20 \%$ of fresh weight yield. This also required more time for harvesting and sorting. Examining individual sampling unit yields plotted against weeks to harvest (Fig. 5) show that smaller yields were clustered at either 
end of the plot (i.e., harvests with both the least and the greatest time from sowing to harvest had smaller marketable yields). A workable harvest schedule should allow at least 4 weeks for regrowth between harvests, but also harvest before plants become stressed or damaged. Figure 6 shows the seasonal distribution of yield for both seasons of Study B expressed as total kilograms fresh spinach harvested from each $60-\mathrm{ft}^{2}$ harvest event area (sum of six $10-\mathrm{ft}^{2}$ plots). A market grower could use a similar schedule, but tailor the area/amount harvested based on market needs and plant growth and quality. Although the only clear pattern is larger yields early in the season and smaller yields later, it is clear that periodic harvests are possible for direct marketing opportunities like farmers' markets, community-supported agriculture, or sales to schools, retail outlets, or restaurants.

Temperatures. Daily minimum and maximum air temperatures under the rowcover are shown in Figs. 7 and 8 for Studies A and B, respectively. Average outside air temperature over the course of Study A was $37.6^{\circ} \mathrm{F}$, and average inside air temperature without rowcover was 49.1 ${ }^{\circ} \mathrm{F}$ and average air temperature inside the high tunnel and under rowcover was $55.3{ }^{\circ} \mathrm{F}$, which were, respectively, 7.8 and $11.5^{\circ} \mathrm{F}$ warmer than outside air temperature. Maximum air temperatures inside the high tunnel and under the rowcover reached $120.5^{\circ} \mathrm{F}$ in season $\mathrm{l}$ and $114.4^{\circ} \mathrm{F}$ in season 2. Uncovered interior air temperature maximums were only slightly lower at 109.2 and $104.7^{\circ} \mathrm{F}$ in seasons 1 and 2 , respectively. The extreme temperatures severely impeded spinach growth in the early part of their growth cycle, and hastened bolting in the later part of the growth cycle.

The extreme outside minimum air temperature $\left(-7.9^{\circ} \mathrm{F}\right)$ occurred in January of season 1 , but at this time, inside air temperature was $12.6^{\circ} \mathrm{F}$ and undercover air temperature was $22.7^{\circ} \mathrm{F}$. In season 2 , the extreme minimum air temperature reached $4.5^{\circ} \mathrm{F}$ while inside air temperature was $17.0^{\circ} \mathrm{F}$ and air temperature undercover was $31.7^{\circ} \mathrm{F}$.

In Study B, average outside air temperature was $41.7^{\circ} \mathrm{F}$, and average inside air temperature without rowcover was $51.6{ }^{\circ} \mathrm{F}$ and average air

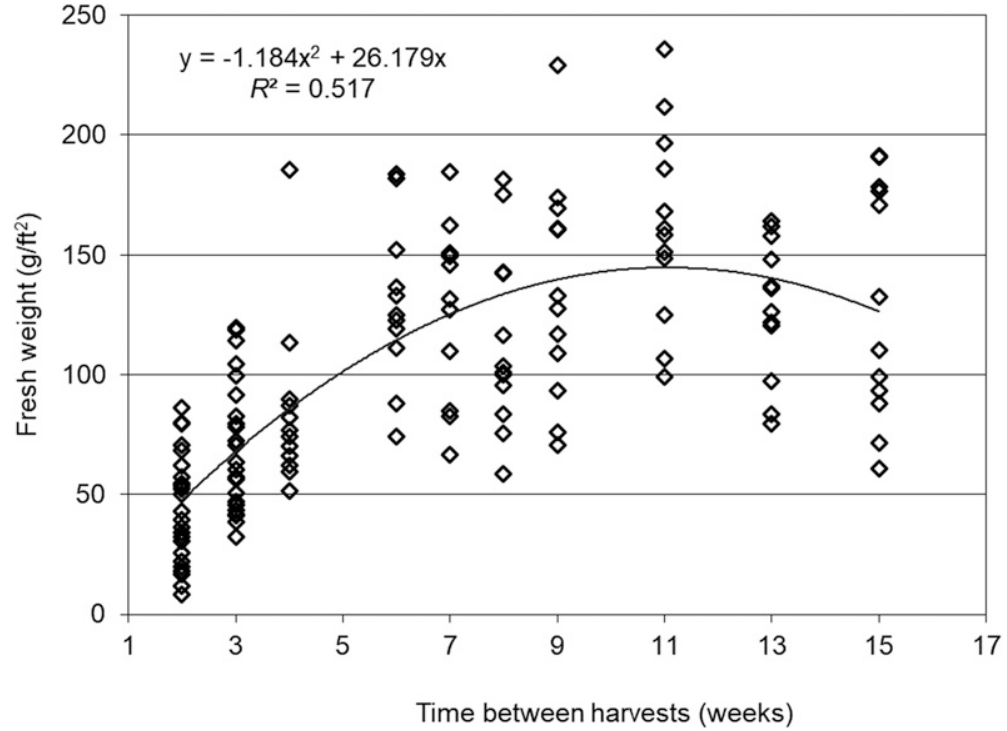

Fig. 5. Regression of individual sampling unit yields of 'Bloomsdale Longstanding' spinach on weeks of growth before or between harvests. A quadratic response was the best fit to the data in Study B. Harvest intervals ranged from 2 to 15 weeks at Alcalde, NM; $1 \mathrm{~g} / \mathrm{ft}^{2}=0.0353 \mathrm{oz} / \mathrm{ft}^{2}=0.0108 \mathrm{~kg} \cdot \mathrm{m}^{-2}$.

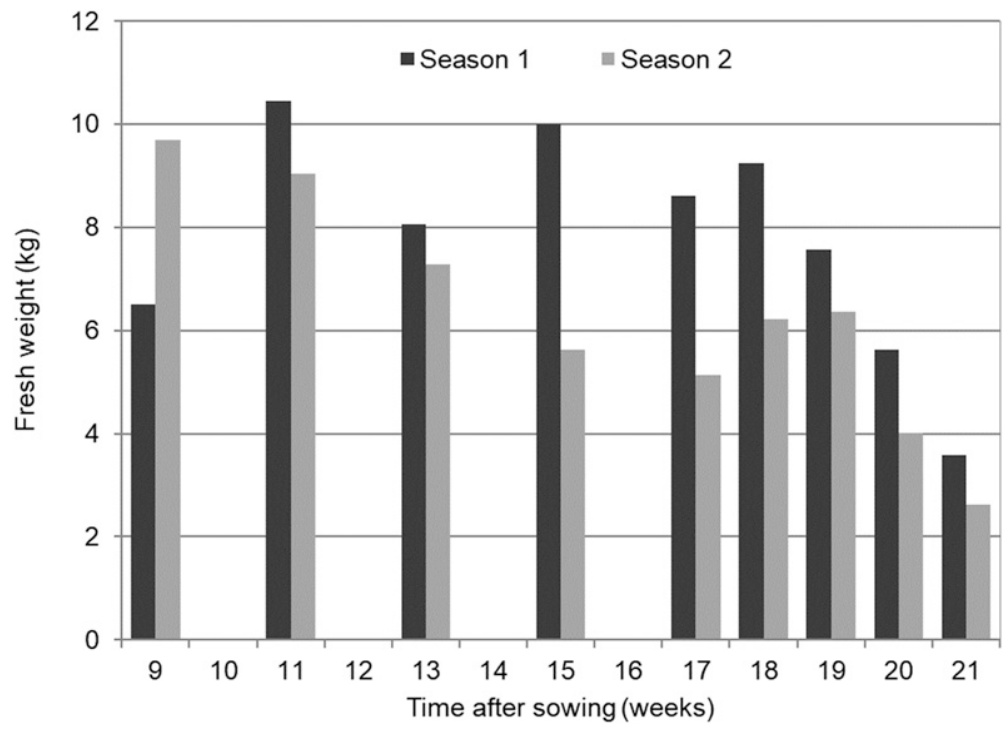

Fig. 6. Seasonal distribution of 'Bloomsdale Longstanding' spinach yield sown in a high tunnel on 15 Oct. and harvested at four different harvest schedules in two seasons (2013-14 and 2014-15) and harvested according to four harvest schedules: 9,17 , and 20 weeks after sowing; 11,18 , and 21 weeks after sowing; 13,19 , and 21 weeks after sowing; and 15, 18, and 21 weeks after sowing. Yield is expressed as fresh weight in kilograms per $60-\mathrm{ft}^{2}\left(5.6 \mathrm{~m}^{2}\right)$ harvest area, which is the total area harvested at each harvest interval for each treatment; $1 \mathrm{~kg} / 60 \mathrm{ft}^{2}=$ $0.0367 \mathrm{lb} / \mathrm{ft}^{2}=0.1794 \mathrm{~kg} \cdot \mathrm{m}^{-2}$.

temperature inside the high tunnel and under the rowcover was $54.8^{\circ} \mathrm{F}$. These were, respectively, 9.9 and $13.1^{\circ} \mathrm{F}$ warmer than outside. Maximum air temperatures inside the high tunnel and under the rowcover were 112.3 and $112.6^{\circ} \mathrm{F}$ in seasons 1 and 2 , respectively. Uncovered maximum air temperatures were 100.7 and $100.3{ }^{\circ} \mathrm{F}$ in seasons $\mathrm{l}$ and 2 , respectively.

In season 1 , the extreme outside minimum air temperature $(6.8$ ${ }^{\circ} \mathrm{F}$ ) occurred in January, and at this time, inside air temperature was $16.2^{\circ} \mathrm{F}$ and undercover was 25.0 ${ }^{\circ} \mathrm{F}$. In season 2 , outside extreme minimum reached $2.1^{\circ} \mathrm{F}$, whereas 


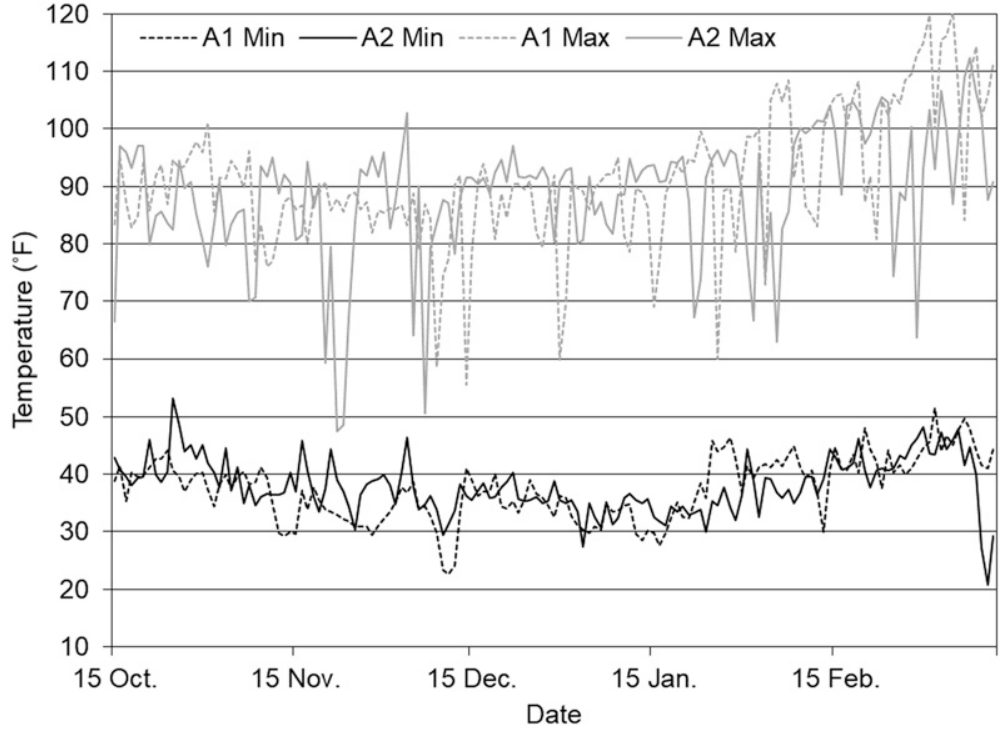

Fig. 7. Minimum (Min) and maximum (Max) daily air temperatures $1 \mathrm{ft}(0.3 \mathrm{~m})$ above soil level under the rowcover in the high tunnel from 15 Oct. to 15 Mar. at Alcalde, NM. Al = season 1 of Study A (2012-13), A2 = season 2 of Study A (2013-14). Temperatures were logged every $30 \mathrm{~min}$, and daily minimum and maximum were acquired by preselected data filter; $\left({ }^{\circ} \mathrm{F}-32\right) \div 1.8={ }^{\circ} \mathrm{C}$.

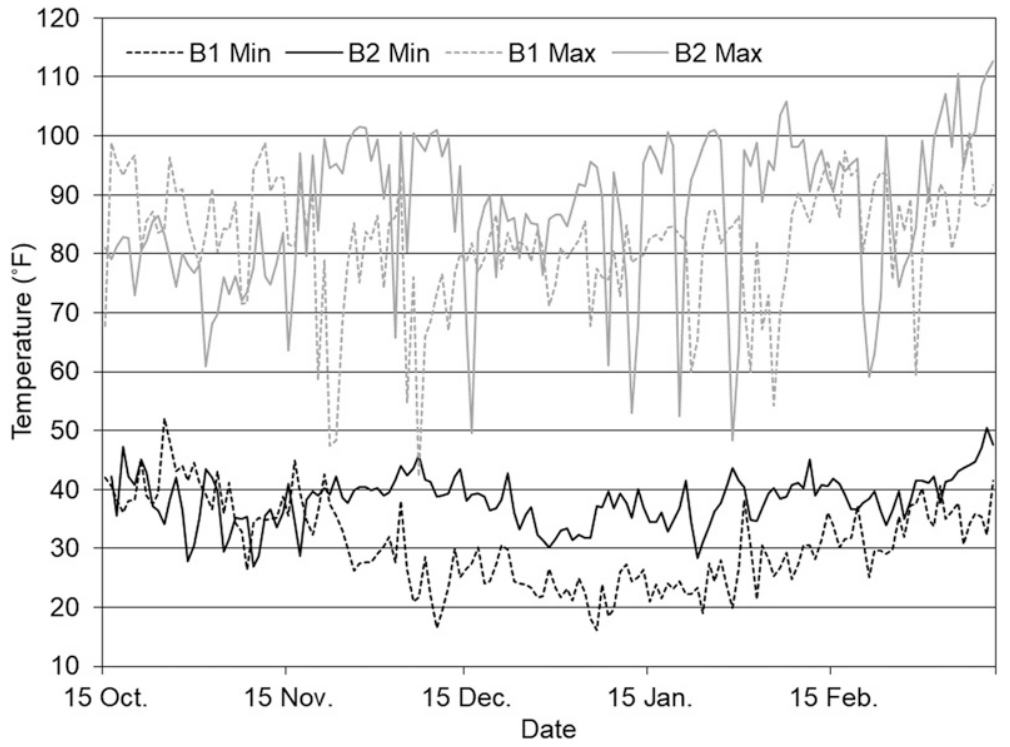

Fig. 8. Minimum (Min) and maximum (Max) daily air temperatures $1 \mathrm{ft}(0.3 \mathrm{~m})$ above ground under the rowcover in the high tunnel 15 Oct. to $15 \mathrm{Mar}$. at Alcalde, NM. B1 = season 1 of Study B (2013-14), B2 = season 2 of Study B (2014-15). Temperatures were logged every $30 \mathrm{~min}$, and daily minimum and maximum were acquired by preselected data filter; $\left({ }^{\circ} \mathrm{F}-32\right) \div 1.8={ }^{\circ} \mathrm{C}$.

inside was $30.2^{\circ} \mathrm{F}$ and undercover was $35.5^{\circ} \mathrm{F}$.

Looking at monthly extremes inside the high tunnel and under the rowcover, daily maximum air temperatures in excess of $100{ }^{\circ} \mathrm{F}$ occurred in March in both seasons of both studies, while such extreme temperatures occurred in February in all but season 1 of Study B. In general, overall average air temperatures under rowcover for Study A were similar across seasons (temperature 55.9 and $54.7^{\circ} \mathrm{F}$ for seasons 1 and 2, respectively), and this appeared to correspond to the lack of significant difference in yield data across these seasons. For Study B, however, season 1 (average temperature $48.5^{\circ} \mathrm{F}$ ) was much cooler than season $2\left(54.8^{\circ} \mathrm{F}\right)$. In season $\mathrm{l}$ of Study B, temperatures above $100{ }^{\circ} \mathrm{F}$ in the high tunnel were recorded only in March, but in season 2, they were recorded for every month except October.

Overall, high temperatures inside the high tunnel and undercover were similar across all phases of the study with the exception of season 2 of Study B, which had higher temperatures overall. Perhaps these higher temperatures were more detrimental to overall yield than the extreme lows. The average temperature advantage inside the high tunnel but not under rowcover ranged from 4.0 to $15.9^{\circ} \mathrm{F}$ across seasons in these studies. Average temperature advantage under rowcover ranged from 10.2 to $20.6{ }^{\circ} \mathrm{F}$ across seasons of these studies. These include temperature advantage at times when outside temperatures may be high and venting appropriate to reduce inside temperature. The high tunnels in which the studies took place were constructed and operated as low-input, low-maintenance systems and assessed to determine their utility for year-round production. Closer attention to high temperatures and venting could prolong the harvest season, and improvements in design (such as roll-up sidewalls) could enhance stand establishment and uniformity by promoting more ideal conditions for germination in the early season.

\section{Conclusion}

Both studies demonstrated that spinach can be grown through the winter in high tunnels in northern New Mexico. Yield per unit area was close to that reported by others: lower on average than reported in Nevada [363 g/ $\mathrm{ft}^{2}$ (Bishop et al., 2010)], but greater than that reported in Utah [204 g/ $/ \mathrm{ft}^{2}$ (Drost et al., 2012)], both grown under similar circumstances. Similar to our study, Grahn et al. (2015) noted numerous interactions among season, location, planting date, and cultivar in relation to yield. In this study, only one cultivar was used, so yield results are not readily applicable to other varieties or crops. Seasonal total yields (for the entire cropped area of the hoop house or $240 \mathrm{ft}^{2}$ ) through the study ranged from 62.6 to $81.6 \mathrm{~kg}$, yielding from 1.3 to $5.1 \mathrm{~kg}$ weekly throughout the 
harvest season. The high tunnels provided anywhere from 10 to $20^{\circ} \mathrm{F}$ temperature advantage compared with outside ambient temperatures. However, this includes times when outside ambient temperature reached $80{ }^{\circ} \mathrm{F}$ and inside temperature rose to $100{ }^{\circ} \mathrm{F}$ or above, for example. Temperature advantage of only 3.4 to $10.3^{\circ} \mathrm{F}$ was reported in a similar test at two locations in Washington State (Borrelli et al., 2013). Soil temperature inside and undercover averaged 7.4 to $9.5^{\circ} \mathrm{F}$ warmer than outside soil temperature. Borrelli et al. (2013) reported a soil temperature advantage of 2.5 to $5.5^{\circ} \mathrm{F}$. More careful attention to venting high tunnels on hot days may reduce heat stress in plants and prolong the harvest season, increase yields, or both. In addition, with added venting features on the high tunnels, sowing could be done earlier than 15 Oct., again, resulting in a prolonged harvest season.

\section{Literature cited}

Borrelli, K., R.T. Koenig, B.M. Jaeckel, and C.A. Miles. 2013. Yield of leafy greens in high tunnel winter production in the northwest United States. HortScience 48:183-188.

Bishop, C., H. Gatzke, and K.R. Curtis. 2010. Small farm hoop house production of vegetables in desert climates, costs \& returns, 2010. Univ. Nevada Coop. Ext. Spec. Publ. 10-11.

Blomgren, T. and T. Frisch. 2007. High tunnels: Using low-cost technology to increase yields, improve quality and extend the season. 20 Dec. 2017. <http://sustainablefarming.rutgers.edu/wp-content/uploads/ 2014/09/High-Tunnel-Case-StudiesSARE-UVM-2007.pdf>.

Bowman, R.A. 1988. A rapid method to determine total phosphorus in soils. Soil Sci. Soc. Amer. J. 52:1301-1304.

Coleman, E. 2009. The winter harvest handbook: Year-round vegetable production using deep-organic techniques and unheated greenhouses. Chelsea Green, White River Junction, VT.

Donnell, J., J.T. Biermacher, and S. Upson. 2011. Economic potential of using high tunnel hoop houses to produce fruits and vegetables. Southern Agr. Econ. Assoc. (SAEA) Annu. Mtg., Corpus Christi, TX, 5-8 Feb. 2011.

Dorich, R.A. and D.W. Nelson. 1984. Evaluation of manual cadmium reduction methods for determination of nitrate in potassium chloride extracts of soils. Soil Sci. Soc. Amer. J. 48:72-75.

Drost, D., B. Black, and T. Ernst. 2012. High tunnel winter spinach production. 20 Jan. 2019. <https://digitalcommons.usu. edu $/$ cgi $/$ viewcontent .cgi? article $=1298 \&$ context $=$ extension_curall $>$.

Emmert, E.M. 1955. Low-cost plastic greenhouses. Univ. Kentucky, Kentucky Agr. Expt. Sta. Prog. Rpt. 28.

Giacomelli, G.A. 2009. Engineering principles impacting high-tunnel environments. HortTechnology 19:30-33.

Grahn, C.M., C. Benedict, T. Thornton, and C. Miles. 2015. Production of babyleaf salad greens in the spring and fall seasons in northwest Washington. HortScience 50:1467-1471.

Halweil, B. 2002. Home grown: The case for local food in a global market. Worldwatch Paper 163. Worldwatch Institute, Washington, DC.

Hecher, E.A.D.S., C.L. Falk, J. Enfield, S.J. Guldan, and M.E. Uchanski. 2014. The economics of low-cost high tunnels for winter vegetable production in the southwestern United States. HortTechnology 24:7-15.

Hinrichs, C.C. 2003. The practice and politics of food system localization. J. Rural Stud. 19:33-45.

Jimenez, D., R. Walser, and R. Torres. 2005. Hoop house construction for New Mexico: 12 -ft $\times 40-\mathrm{ft}$ hoop house. New Mexico State Univ. Coop. Ext. Serv. Circ. 606. 27 Jan. 2018. <http://cahe.nmsu. edu/pubs/_circulars/CR-606.pdf>.

Katzman, L.S., A.G. Taylor, and R.W. Langhans. 2001. Seed enhancements to improve spinach germination. HortScience 36:979-981.

Knewtson, S.J.B., E.E. Carey, and M.B. Kirkham. 2010. Management practices of growers using high tunnels in the central Great Plains of the United States. HortTechnology 20:639-645.

Lamont, W.J. and M.D. Orzolek. 2003. 2003 High tunnel production manual. Ctr. Plasiculture, Pennsylvania State Univ., University Park.

Lamont, W.J. 2009. Overview of the use of high tunnels worldwide. HortTechnology 19:25-29.

Maynard, D.N. and G.J. Hochmuth. 2007. Knott's handbook for vegetable growers. Wiley. Hoboken, NJ.

Morrison, K.T., T.A. Nelson, and A.S. Ostry. 2011. Methods for mapping local food production capacity from agricultural statistics. Agr. Syst. 104:491-499.
Munter, R.C., R.A. Grande, and R.M. Barnes. 1981. Plant analysis and soil extract analysis by ICP-atomic emission spectrometry, p. 653-672. In: R.M. Barnes (ed.). Developments in atomic plasma spectrochemical analysis. Heyden and Son, London, UK.

Neal, A. 2011. Winter...the perfect time to visit a farmers market. Know your farmer know your food. 6 Apr. 2016. <https://www.elixirhealth.com/ articles/winter-\%E2\%80\%A6the-perfecttime-to-visit-a-farmers-market>.

New Mexico Climate Center. 2019. Weather stations and data retrieval. 14 Jan. 2019. <weather.nmsu.edu/coop/ request/station/290245/data/>.

New Mexico Department of Agriculture. 2015. New Mexico's 75 farmers markets good for economy, community. 14 Jan. 2019. <http://www.nmda.nmsu.edu/ 2015/08/11413/>.

New Mexico Farmers' Market Association. 2019. Find a market. 14 Jan. 2019. <http://farmersmarketsnm.org/find-amarket/?_sfm_wpsl_winter=WINTER\% 20HOURS $>$.

Peters, C.J., N.L. Bills, A.J. Lembo, J.L. Wilkins, and G.W. Fick. 2009. Mapping potential foodsheds in New York State: A spatial model for evaluating the capacity to localize food production. Renew. Agr. Food Syst. 24:72-84.

Rose, N., E. Serrano, K. Hosig, C. Haas, D. Reaves, and S.M. Nickols-Richardson. 2008. The 100-mile diet: A community approach to promote sustainable food systems impacts dietary quality. J. Hunger Environ. Nutr. 3:270-285.

Soltanpour, P.N. and A.P. Schwab. 1977. A new soil test for simultaneous extraction of macro- and micro-nutrients in alkaline soils. Commun. Soil Sci. Plant Anal. 8:195-207.

Suganuma, N. and H. Ohno. 1984. Role of the pericarp in reducing spinach (Spinacia oleracea L.) seed germination at supra-optimal temperatures. J. Jpn. Soc. Hort. Sci. 53:38-44.

Swiader, J.M. and G.W. Ware. 2002. Cole crops: Cabbage, broccoli, cauliflower and related crops, p. 267-271. In: J.M. Swiader, G.W. Ware, and J.P. McCollum (eds.). Producing vegetable crops. Interstate, Danville, IL.

U.S. Department of Agriculture. 2008. Soil survey of Rio Arriba area, New Mexico, parts of Rio Arriba and Sandoval counties. 20 Jan. 2019. <https://www. nrcs.usda.gov/Internet/FSE_ MANUSCRIPTS/new_mexico/ NM650/0/Rio\%20Arriba\%20Area\% 20NM.pdf>. 
U.S. Department of Agriculture. 2017a. School meals: Healthy hunger-free kids act. 14 Jan. 2019. <www.fns.usda.gov/ school-meals/healthy-hunger-free-kids-act>.

U.S. Department of Agriculture. 2017b. Farm to school grants. 14 Jan. 2019. $<$ ht ps://www.fns.usda.gov/ farmtoschool/farm-school-grantprogram>.

Upson, S. 1998. Hooping it up: Observations from two years of hoop house vegetable trials. 14 Jan. 2019. <https:// www.noble.org/news/publications / ag-news-and-views/1998/april/hoopingit-up-observations-from-two-years-ofhoop-house-vegetable-trials $/>$.

Walz, E. 2004. Final results of the fourth national organic farmers' survey: Sustaining organic farms in a changing organic marketplace. 14 Jan. 2019. <http://ofrf. org/sites/ofrf.org/files/docs/pdf/ 4thsurvey_results.pdf $>$.
Wells, O.S. and J.B. Loy. 1993. Rowcovers and high tunnels enhance crop production in the northeastern United States. Hort Technology 3:92-95.

Western Regional Climate Center. 2019. Cooperative climatological data summaries. Alcalde, New Mexico. 20 Jan. 2019. <https://wrcc.dri.edu/cgi-bin/ cliMAIN.pl?nm0245>. 